\title{
Community based intervention: Local village preparedness in prevention and control of COVID-19
}

\author{
Muhamad Jauhar, ${ }^{*}$ Rasdiyanah, ${ }^{2}$ Lita Heni Kusumawardani, ${ }^{3}$ Utami Rachmawati, ${ }^{4}$ I Gusti Ayu Putu \\ Desy Rohana ${ }^{5}$
}

${ }^{1}$ Department of Nursing, Health Polytechnic of Ministry of Health Semarang, Semarang, Indonesia ${ }^{2}$ Department of Nursing, Faculty of Medicine and Health Sciences, Universitas Islam Negeri Alauddin Makassar, Indonesia ${ }^{3}$ Department of Nursing, Faculty of Health Sciences, Universitas Jenderal Soedirman, Purwokerto, Indonesia ${ }^{4}$ Department of Community Nursing, Faculty of Nursing, Universitas Indonesia, Depok, Indonesia ${ }^{5}$ Department of Nursing, Health Polytechnic of the Ministry of Health Palembang, Baturaja, Indonesia

SUBMITTED: 7 February 2021 REVISED: 31 July 2021 ACCEPTED: 4 October 2021

KEYWORDS COVID-19 pandemic Community Empowerment Prevention Preparedness
ABSTRACT The COVID-19 pandemic has become a global concern since it has severely affected various aspects of life such as health, economy, society, culture, and religion. Community empowerment in breaking the chain of region-based COVID-19 spread is an effective approach that can be taken. This intervention is an important alternative measure to slow the morbidity and mortality of COVID-19 that continue to occur in Indonesia. This article aimed to describe the implementation of a community-based COVID-19 prevention program that was conducted among 280 families in six sub-districts in Brebes Regency from May to June 2020. The assessment used a questionnaire of COVID-19 transmission risk, with a total of 29 indicators developed based on references from the Indonesian Ministry of Health. The preliminary assessment of our program found several aspects that were related to the risk of COVID-19 transmission in the village and observed that there was insufficient public knowledge about COVID-19 including poor practice of health protocols and the negative stigma of society towards patients with COVID-19. The community-based program involved several activities, which namely consisted of program introduction, coordination with stakeholders, community assessments, group discussions, village community deliberations, health education about COVID-19 and 6 step hand washing, distribution of cloth masks, socialization of mask usage and care, socialization of pregnancy checks during the pandemic, provision of hand washing facilities in front of the house, activities evaluation, follow-up plans, and closings. Furthermore, the aforementioned activities also used videos, posters, leaflets, WhatsApp, as well as Zoom Cloud Meetings as the media. The evaluation phase of the program showed a better understanding related to COVID-19 and health protocol practice in each region. Community empowerment and collaboration with health care facilities can be pursued as a frontline solution to tackle the transmission of COVID-19. Good support and active community participation can contribute to improve the public health status. (c) The Journal 2021. This article is distributed under a Creative Commons Attribution-ShareAlike 4.0 International license.

\section{Introduction}

Corona Virus Disease 2019 or COVID-19 is a disease caused by infection with the latest type of Severe Acute Respiratory Syndrome Virus 2 (SARSCOV-2), which is currently referred to as the novel coronavirus (2019nCoV). ${ }^{1}$ The swift spread of this disease has infected over 266 million people and caused more than 6.26

\footnotetext{
*Correspondence: muhamadjauhar@poltekkes-smg.ac.id Department of Nursing, Health Polytechnic of Ministry of Health Semarang, Jl. Tirto Agung, Pedalangan, Banyumanik, Semarang 50268, Indonesia
}

million deaths worldwide (Case Fatality Rate / CFR 4.3\%). ${ }^{2}$ In addition, Indonesia is the country with the highest COVID-19 cases in Southeast Asia. One of the factors related to this situation is that Indonesia is located on the international route to China so that it has a high risk of transmitting the COVID-19 virus. ${ }^{3}$ Indonesia reported more than 4.26 million confirmed cases with 144,000 deaths as of December 7, 2021. ${ }^{4}$ The Indonesian government announced a Public Health Emergency (Kedaruratan Kesehatan Masyarakat in Bahasa Indonesia, KKM in short) and established a COVID-19 KKM in Indonesia, which 
must be taken into account. ${ }^{5}$ The spread of COVID-19 has almost reached all provinces in Indonesia with the number of cases and/or the number of deaths increasing dramatically in 2021 and having an impact on political, economic, social, cultural, defense and security aspects, as well as the welfare of the people in Indonesia. ${ }^{5}$

The prevention of KKM is conducted through the implementation of quarantine and the implementation of Clean and Healthy Living Behaviors (PHBS), but it is considered not optimal to break the chain of COVID-19 transmission due to the increasing number of positive cases in Indonesia. ${ }^{6}$ Various policies have been issued by the government in an effort to tackle COVID-19. The countermeasures that have been pursued include the imposition of LargeScale Social Restrictions (PSBB), replacing office and school activities with online-based activities known as Work From Home (WFH), mandatory wearing masks for people who still have to do activities outside the house, social distancing which is currently changing to physical distancing, and the provision of hand sanitizers in public places to build the habit of hand washing which are referred to as the mandatory health protocols. ${ }^{7}$ The lack of information related to objectives and the government's participation in implementing policies makes people less likely to comply, especially in implementing these important health protocols, and one of the reason why is because they must continue to be active in order to fulfill their daily needs despite the pandemic. ${ }^{8}$ These phenomena have not only happened in the epicenters of the pandemic but also happened in several remote provinces in Indonesia.

Central Java ranks $4^{\text {th }}$ as the highest number of positive confirmed cases of COVID-19. Furthermore, Brebes Regency became the COVID-19 red zone in early May 2020. Meanwhile, the data showed that the availability of health service facilities per 100,000 population, 1 polyclinic, 2 Community Health Centre (Puskesmas), and 3 Satellite Puskesmas, with a hospital availability ratio of 0.72 . Statistic Bureau data of 2019 also showed that the top 3 diseases experienced by the population are infectious diseases in the form of diarrhea, Tuberculosis and Dengue Hemorrhagic Fever. With the status of the COVID-19 red zone also indicating the preexisting communicable diseases as the major health problems in the Brebes Regency, it showed how the health protocols and PHBS implementation were still lacking and needed to be addressed.

Upon further investigation, Brebes Regency is the second district with the largest population in Central Java Province, namely $1,809,096$ people live within the area of 176,962.89 hectares (Central Bureau of Statistics, Brebes Regency, 2020). The average rate of population growth is 0.4 with a sex ratio (F/M) of 101.39 and an average length of schooling is 6.20 years, thus indicating the need to increase the potential of population resources in terms of skill development and education. Most of the area of Brebes Regency is lowlands with an average rainfall of $18.94 \mathrm{~mm}$ per month. This condition makes the area have excellent potential for the development of many living aspects, including the steady development of communication and information through Internet access coverage program. Based on environmental studies, its potentials and the urgency of overcoming the lack of health protocols implementation during COVID-19 pandemic, Brebes Regency needs specific interventions that involve community-based COVID-19 prevention preparedness programs.

\section{Method}

This activity was integratedly conducted during interprofessional education and collaborative practice of the field practice service program (KKN) held by the Health Polytechnic of Ministry of Health Semarang during the COVID-19 pandemic. This activity was attended by 11 final year applied health science undergraduate students from nursing, dental nursing, environmental health, midwifery, radiology, and nutrition majors. Students were assigned as volunteers for the COVID-19 village in their respective residences. This activity was done in May-June 2020 in Larangan, Tonjong, Bumiayu, Brebes, Paguyangan, and Bantarkawung, Brebes Districts. Village volunteers coordinated with stakeholders; conducted studies, group discussions, and community meetings; implemented programs, 
Day $1:$ The village volunteers were trained in the form of one-day online seminar with the topics of interprofessional health collaboration in dealing with health problems from the Ministry of Health Republic Of Indonesia also the transmission of COVID-19 infection from the Health Polytechnic of Ministry of Health Semarang, and lastly promotional and preventive efforts of COVID-19 from the Central Java Health Office.

Day 2 to 5 : The village volunteers conducted assessments on families by practicing strict health protocols. The assessment process used a COVID-19 risk of transmission questionnaire through google form encompassing 29 indicators that was developed based on references from the Ministry of Health using the Guttman scale.

Day 7 to 19 : The village volunteers conducted health education about the prevention and transmission of COVID-19, simulating 6-step hand washing using soap, providing hand washing facilities in front of the house, distributing cloth masks, socializing the usage and care of cloth masks, and socializing pregnancy checks during the COVID-19 pandemic. The supporting media such as videos, posters, leaflets, WhatsApp, and Zoom Cloud Meetings.

Day 20 to 22 : The village volunteers conducted activity evaluations, draw up follow-up plans, and reporting the whole completed activities before finally held an online wrapped up session of the program at the $23 \mathrm{rd}$ day.

Figure 1. Flow chart of the steps of community services activities.

evaluated, and published the activities. This activity was funded by Health Polytechnic of Ministry of Health Semarang and non-binding community organizations. The activity is described in the flow chart below:

Village volunteers compiled reports on the results of the assessment in their respective environments, the results of data collection on possible risk factors and causes of COVID-19 transmission if cases were found, the results of socialization, and the results of collaboration in the form of programs carried out to accelerate the process of breaking the chain of transmission of COVID-19. Village volunteers also prepared a followup plan for the program which will be continued by the community. The report was prepared in the form of video and photo documentation of activities. Evaluation of the implementation of this activity was done by field supervisors based on pre-test and posttest scores, daily logbooks, and reports containing assessment results, problem identification, program plans, program implementation and documentary evidence.

\section{Result}

\section{Risk factors of COVID-19 transmission in the community}

Table 1 shows that all families (100\%) have never traveled domestically or internationally in the last 14 days and have never met foreign tourists. There is 1 person $(0.4 \%)$ who has a history of contact with a person who is positive for COVID-19. Data on health issues related to COVID-19 symptoms were obtained, and indicated 4 people (1.4\%) had fever, 4 people $(1.4 \%)$ had cough symptoms, 1 person $(0.4 \%)$ had sore throat, 3 people (1.07\%) complained of shortness of breath, and 4 people (1.4\%) complained of coughs and colds. Furthermore, we also observed the medical history such as diabetes mellitus (1.4\%), hypertension (10.3\%), heart disease (1.07\%), kidney disease $(0.7 \%)$, and lastly bronchitis $(0.4 \%)$. 
Table 1. Risk factors of COVID-19 transmission in the community $(n=280)$

\begin{tabular}{|c|c|c|}
\hline Risk factors & $f$ & $\%$ \\
\hline \multicolumn{3}{|l|}{ Domestic/international travel history } \\
\hline Yes & 0 & 0 \\
\hline No & 280 & 100 \\
\hline \multicolumn{3}{|l|}{ Meeting foreign tourists } \\
\hline Yes & 0 & 0 \\
\hline No & 280 & 100 \\
\hline \multicolumn{3}{|l|}{ Contact with COVID-19 patient history } \\
\hline Yes & 1 & 0.4 \\
\hline No & 279 & 99.6 \\
\hline \multicolumn{3}{|l|}{ Health Issues } \\
\hline \multicolumn{3}{|l|}{ Fever } \\
\hline Yes & 4 & 1.4 \\
\hline No & 276 & 98.6 \\
\hline \multicolumn{3}{|l|}{ Cough } \\
\hline Yes & 4 & 1.4 \\
\hline No & 276 & 98.6 \\
\hline \multicolumn{3}{|l|}{ Sore throat } \\
\hline Yes & 1 & 0.4 \\
\hline No & 279 & 99.6 \\
\hline \multicolumn{3}{|l|}{ Shortness of breath } \\
\hline Yes & 3 & 1.07 \\
\hline No & 277 & 98.93 \\
\hline \multicolumn{3}{|l|}{ Cough or runny nose } \\
\hline Yes & 4 & 1.4 \\
\hline No & 276 & 98.6 \\
\hline \multicolumn{3}{|l|}{ Medical History (Comorbid) } \\
\hline \multicolumn{3}{|l|}{ Diabetes mellitus } \\
\hline Yes & 4 & 1.4 \\
\hline No & 276 & 98.6 \\
\hline \multicolumn{3}{|l|}{ Hypertension } \\
\hline Yes & 29 & 10.3 \\
\hline No & 251 & 89.7 \\
\hline \multicolumn{3}{|l|}{ Heart Disease } \\
\hline Yes & 3 & 1.07 \\
\hline No & 277 & 98.93 \\
\hline \multicolumn{3}{|l|}{ Kidney Disease } \\
\hline Yes & 2 & 0.7 \\
\hline No & 278 & 99.3 \\
\hline \multicolumn{3}{|l|}{ Bronchitis / asthma / pneumonia } \\
\hline Yes & 1 & 0.4 \\
\hline No & 279 & 99.6 \\
\hline \multicolumn{3}{|l|}{ Risk-prone behaviors } \\
\hline Travel history to the COVID-19 red zone & 13 & 4.64 \\
\hline Yes & 267 & 95.36 \\
\hline \multicolumn{3}{|l|}{ No } \\
\hline Residing in the COVID-19 red zone & 142 & 50.7 \\
\hline Yes & 138 & 49.3 \\
\hline No & & \\
\hline Receiving guests from the COVID-19 red & & \\
\hline Yes & 10 & 3.6 \\
\hline No & 270 & 96.4 \\
\hline Visiting sick people & & \\
\hline Yes & 13 & 4.64 \\
\hline No & 267 & 95.36 \\
\hline Undergo dental checks & & \\
\hline Yes & 117 & 41.8 \\
\hline No & 163 & 58.2 \\
\hline Meeting with $>10$ people & & \\
\hline Yes & 95 & 33.9 \\
\hline No & 185 & 66.1 \\
\hline
\end{tabular}


Table 1 (Continued). Risk factors of COVID-19 transmission in the community $(n=280)$

\begin{tabular}{|c|c|c|}
\hline Risk factors & $f$ & $\%$ \\
\hline \multicolumn{3}{|c|}{ COVID-19 related Knowledge } \\
\hline Yes & 179 & 63.6 \\
\hline No & 102 & 36.4 \\
\hline \multicolumn{3}{|c|}{ Causes of COVID-19 } \\
\hline Yes & 176 & 62.9 \\
\hline No & 104 & 37.1 \\
\hline \multicolumn{3}{|c|}{ Transmission of COVID-19 } \\
\hline Yes & 200 & 71.4 \\
\hline No & 80 & 28.6 \\
\hline \multicolumn{3}{|c|}{ Prevention of COVID-19 } \\
\hline Yes & 197 & 70.4 \\
\hline No & 83 & 29.6 \\
\hline \multicolumn{3}{|c|}{$\begin{array}{l}\text { COVID-19 prevention behavior } \\
\text { Availability of hand washing facilities }\end{array}$} \\
\hline Yes & 86 & 30.7 \\
\hline No & 194 & 69.3 \\
\hline \multicolumn{3}{|c|}{6 step hand washing knowledge } \\
\hline Yes & 129 & 46.07 \\
\hline No & 151 & 53.93 \\
\hline \multicolumn{3}{|c|}{ Availability of masks } \\
\hline Yes & 260 & 92.9 \\
\hline No & 20 & 7.1 \\
\hline \multicolumn{3}{|c|}{ Wearing masks when outdoors } \\
\hline Yes & 208 & 74.3 \\
\hline No & 72 & 25.7 \\
\hline \multicolumn{3}{|c|}{ Nutritious food consumption } \\
\hline Yes & 187 & 66.8 \\
\hline No & 93 & 33.2 \\
\hline \multicolumn{3}{|c|}{ Sunbathing in the morning } \\
\hline Yes & 58 & 20.7 \\
\hline No & 222 & 79.3 \\
\hline \multicolumn{3}{|c|}{$\begin{array}{l}\text { COVID-19 related perception } \\
\text { Agreeing to ostracize COVID-19 patients }\end{array}$} \\
\hline Yes & 58 & 20.7 \\
\hline No & 222 & 79.3 \\
\hline Total & 280 & 100 \\
\hline
\end{tabular}

Furthermore, Table 1 also explains that as many as 13 people (4.64\%) have a history of travel to the COVID-19 red zone, 142 people (50.7\%) live in the COVID-19 red zone, and 10 people (3.6\%) have received guests from the COVID-19 red zone. Further assessment of the COVID-19 related knowledge also found $29.6 \%$ of the villagers did not know about the COVID-19 preventive procedures whilst as many as $4.64 \%$ of them visited the sick person in the neighborhood. Preventive behaviors related to COVID-19 are still lacking, as shown by $9.3 \%$ who do not have hand washing facilities in front of the house, $53.93 \%$ do not practice 6 step hand washing, $7.1 \%$ did not have a mask, $25.7 \%$ did not use a mask when leaving the house, $33.2 \%$ did not consume nutritious food, and lastly $42.5 \%$ did not sunbathe every morning.

Poor understanding of COVID-19 poses a risk of spreading the contagious disease in the community since it leads to low practice of health protocols. This was indicated by as many as 102 people (36.4\%) did not know the meaning of COVID-19, 104 people (37.1\%) did not know the cause of COVID-19, 80 people $(28.6 \%)$ did not know how COVID-19 is transmitted, besides 117 people (41.8\%) still undergo dental examinations at the clinic and 95 people (33.9\%) still held meetings with more than 10 people. Furthermore, as many as 58 people (20.7\%) agreed that COVID-19 patients should be ostracized.

Table 2 shows there were 4 people who were 
Table 2. Risk factors of COVID-19 transmission in the community based on pregnant women as a vulnerable group $(n=4)$

\begin{tabular}{lll}
\hline Risk factors & $\mathbf{f}$ & $\%$ \\
\hline Vulnerable groups & & \\
Pregnant women & & \\
$\quad$ Yes & 4 & 100 \\
$\quad$ No & 0 & 0 \\
Do online pregnancy checks & & \\
$\quad$ Yes & 1 & 25 \\
$\quad$ No & 3 & 75 \\
\hline
\end{tabular}

Table 3. Risk factors of COVID-19 transmission in the community based on breastfeeding mother as a vulnerable group $(n=17)$

\begin{tabular}{lll}
\hline Risk factors & $\mathbf{f}$ & $\%$ \\
\hline Vulnerable groups & & \\
Breastfeeding Mother & & \\
$\quad$ Yes & 17 & 100 \\
$\quad$ No & 0 & 0 \\
Know how to breastfeed & & \\
$\quad$ Yes & 3 & 17.6 \\
No & 14 & 82.4 \\
\hline
\end{tabular}

pregnant, and only 1 person (25\%) had an online pregnancy checkup. Table 3 describes as many as 17 people were breastfeeding, while $82.4 \%$ of them did not know how to breastfeed their babies during the pandemic.

The following Table 4 describes the implementation of village volunteer activities based on health problems that emerged during the assessment, the form of activities agreed by the community, and the results of the activities.

Evaluation of village volunteer activities was done, namely all activities that have been planned with the community, and followed by the community in the target area. However, after assisting village volunteers, it was still found that some people had not fully applied health protocols such as wearing masks and keeping their distance when gathering. There needs to be cooperation and responsibility from village officials, community leaders, and family heads to remind each other so that the transmission of COVID-19 in the community can be minimized. Village volunteers collaborated with cross-professional health workers as needed. Village volunteers provided health education based on health problems that arise during the assessment. Activities were done online or through in-person home visits.
The community actively participated in activities and conducted question and answer discussions with village volunteers and health workers. The public received accurate and reliable COVID-19 information from village volunteers and health workers so as to minimize misperceptions. The community gave a positive response through the support provided by community leaders, religious leaders, and all components of society. The community will follow up on activities that have been initiated by village volunteers as an effort to prevent the transmission of COVID-19 in their respective regions.

\section{Discussion}

\subsection{Overview of Health Problems in the Community}

The assessment results and problems arising from the COVID-19 pandemic which were found in six districts of Brebes encourage various activities to better handle and prevent the transmission of COVID-19 that continues to increasingly spread. Health-related problems that arise based on the results of the study are: 1) lack of knowledge about COVID-19 as indicated by $36.4 \%$ of the public do not understand the meaning of COVID-19, $37.1 \%$ of the public do not know the causes of COVID-19, and $28.6 \%$ of the villagers do not know how COVID-19 is transmitted; 2) Health behaviors tend to be at risk, indicated by $69.3 \%$ of people who do not have hand washing facilities in front of the house, $53.93 \%$ of people do not know and practice washing hands 6 steps, 7.1\% of people do not have masks, $25.7 \%$ of people do not use masks when leaving the house, $41.8 \%$ still had dental check-ups at the clinic, and $33.9 \%$ still had meetings with more than 10 people; 3) The ineffectiveness of dietary management as indicated by $33.2 \%$ of people not consuming nutritious food during the COVID-19 pandemic; and lastly, 4) The risk of disease is characterized by several people having comorbidities such as diabetes mellitus, hypertension, heart disease, kidney disease, lung disease and some of the women are pregnant.

Based on the results of the study, 1 person (0.4\%) had a history of contact with people who were positive for COVID-19. A history of contact with 
Table 4. Village volunteer activities

\begin{tabular}{|c|c|c|c|}
\hline No. & Health problems & Implementation & Results \\
\hline 1 & $\begin{array}{l}\text { Lack of family knowledge about } \\
\text { preventing transmission of } \\
\text { COVID-19 }\end{array}$ & $\begin{array}{l}\text { Health education about } \\
\text { preventing the spread of } \\
\text { COVID-19 }\end{array}$ & $\begin{array}{l}\text { The family is enthusiastic and active in the } \\
\text { question and answer discussion. } \\
\text { Families are able to explain the prevention of } \\
\text { COVID-19 transmission. }\end{array}$ \\
\hline 2 & $\begin{array}{l}\text { Behavior that is at risk of } \\
\text { transmitting COVID-19 in the } \\
\text { community }\end{array}$ & $\begin{array}{l}\text { Health education through } \\
\text { posters and videos on health } \\
\text { protocols (use and care of } \\
\text { masks) } \\
\text { Distribution of free cloth masks } \\
\text { masker }\end{array}$ & $\begin{array}{l}\text { The community is able to demonstrate the use } \\
\text { and care of masks. } \\
\text { People use masks when doing activities } \\
\text { outside the home. }\end{array}$ \\
\hline 3 & $\begin{array}{l}\text { Lack of public knowledge about } \\
\text { hand washing } 6 \text { steps }\end{array}$ & $\begin{array}{l}\text { Health education on how to } \\
\text { wash your hands in } 6 \text { steps } \\
\text { properly with interactive videos }\end{array}$ & $\begin{array}{l}\text { The community is able to demonstrate the } \\
\text { correct 6-step hand washing. } \\
\text { The community has facilities and } \\
\text { infrastructure for hand washing in front of the } \\
\text { house. }\end{array}$ \\
\hline 4 & $\begin{array}{l}\text { Lack of knowledge of pregnant } \\
\text { women about care and } \\
\text { antenatal care during the } \\
\text { pandemic }\end{array}$ & $\begin{array}{l}\text { Health education about simple } \\
\text { and independent prenatal care } \\
\text { and checkups by pregnant } \\
\text { women }\end{array}$ & $\begin{array}{l}\text { Pregnant women as a vulnerable group carry } \\
\text { out simple antenatal care and check-ups } \\
\text { independently. }\end{array}$ \\
\hline
\end{tabular}

a person who is confirmed positive for COVID-19 can increase the risk of transmitting COVID-19. Judging from the mode of transmission, transmission occurs through droplets from the nose or mouth of a person with COVID-19 while breathing or coughing. ${ }^{12}$ They can enter the body directly through inhalation from an infected person. Indirect transmission occurs because the splashed droplets falls from the patient and stick to the surface of objects around the patient. ${ }^{13}$ Someone who touches these objects/ surfaces will get infected if they touch their eyes, nose or mouth.

The results of the study also showed that $4.64 \%$ had a history of travel to the COVID-19 red zone, $50.7 \%$ lived in the COVID-19 red zone, 3.6\% had received guests from the COVID-19 red zone, and $4.64 \%$ visited the sick. In addition, as many as $29.6 \%$ did not know how to prevent COVID-19, $69.3 \%$ did not have hand washing facilities in front of their house, $53.93 \%$ did not practice the 6 step handwashing, $7.1 \%$ did not have a mask, $25.7 \%$ did not use a mask when leaving the house, $33.2 \%$ did not consume nutritious food, and $42.5 \%$ do not sunbathe every morning. These indicators found from the assessment are not in accordance with the Clean and Healthy Behavior (PHBS) practice that should be performed during the COVID-19 pandemic. PHBS is one of the prominent health programs for the prevention of the COVID-19 that can be in the form of proper and correct hand washing, practicing cough etiquette, maintaining safe physical distance, sunbathing every morning, consuming a balanced nutritious diet, and maintaining personal hygiene. ${ }^{14-16}$ For this reason, providing education about PHBS can be done through health education with the use of printed media (posters), direct socialization, and virtual implementation (online).

\subsection{Description of the Implementation of COVID-19 Prevention Activities in the Community}

Based on the results of the health problems analysis, the aforementioned action plan consists of: 1) online health education on COVID-19 prevention and transmission via WhatsApp and offline activities through home visits with the use of educational media such as posters and videos; 2) The 6-step hand washing offline simulation using soap and the provision of hand washing facilities in front of the house through home-visit; 3) Offline activity of distributing cloth masks and socializing its use through home visits and COVID-19 standby posts at the village level; and 4) Online socialization of antenatal care during the COVID-19 pandemic for pregnant women as one of the vulnerable groups via WhatsApp and offline activities through home 

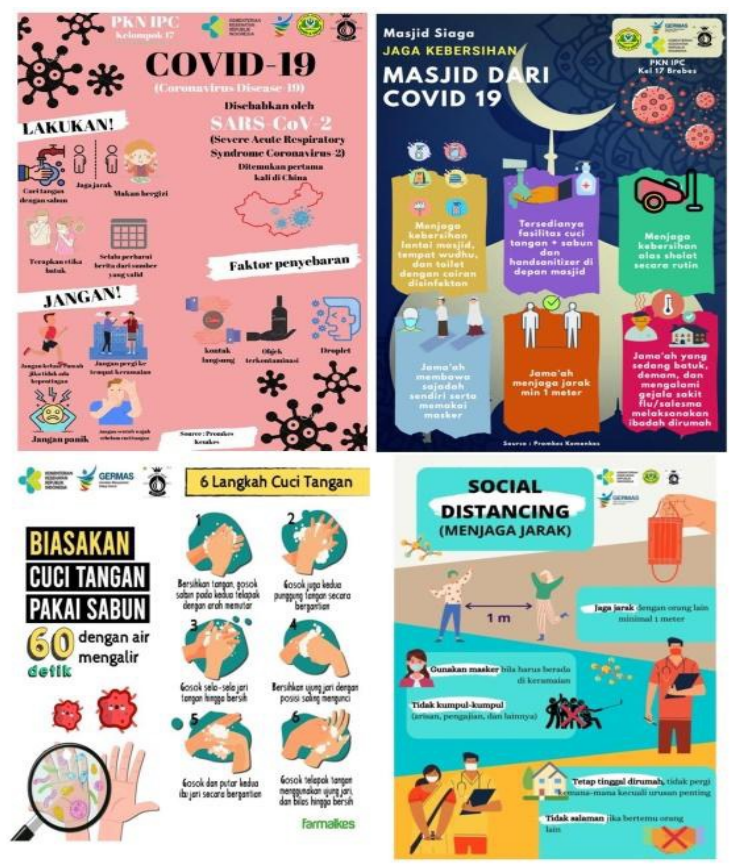

Figure 1. Educational media

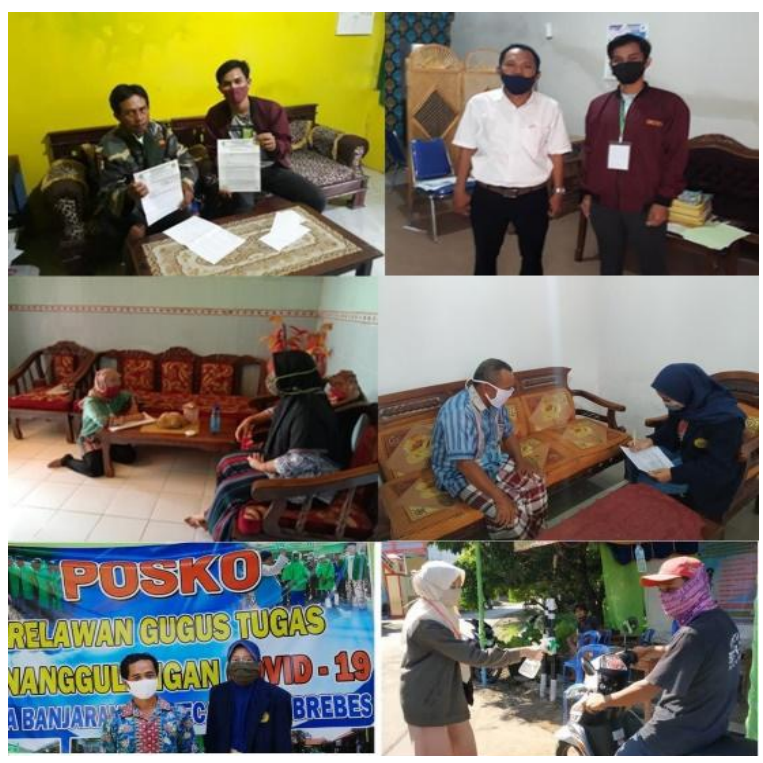

Figure 3. Coordinating Local Permission and Community Data Collection.

visits. The used intervention media are educational posters and videos. Each activity involved community leaders, religious leaders, health cadres, COVID-19 officers at the village level, students, and the local community.

The implementation of various interventions in this activity adopted a policy from the Central Java provincial government, namely "Jogo Tonggo", which is an activity that involves the active role of the

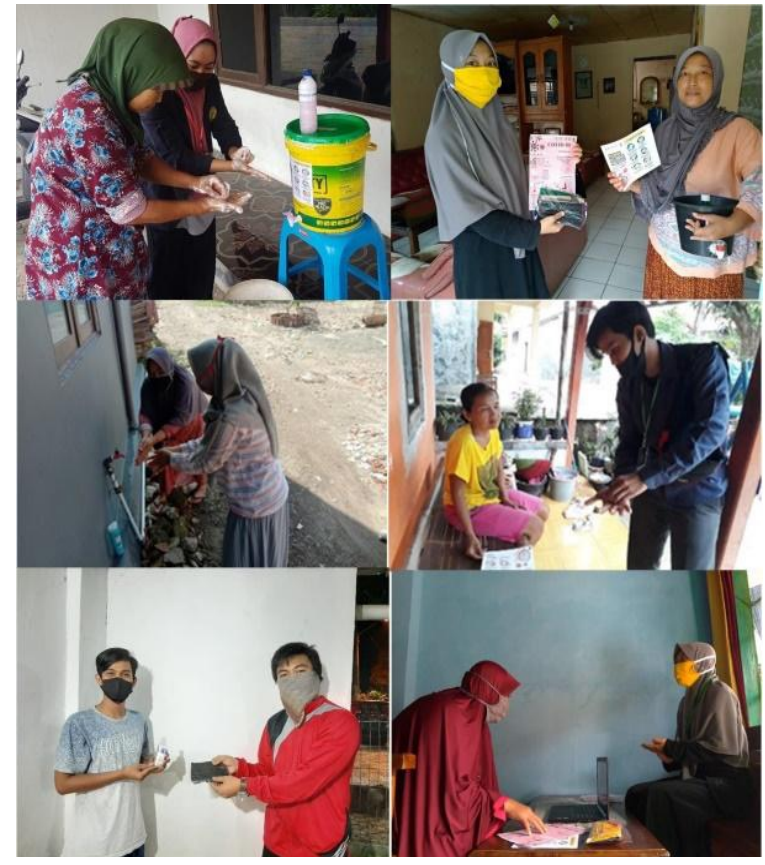

Figure 2. Handwashing and Mask Usage Socialization

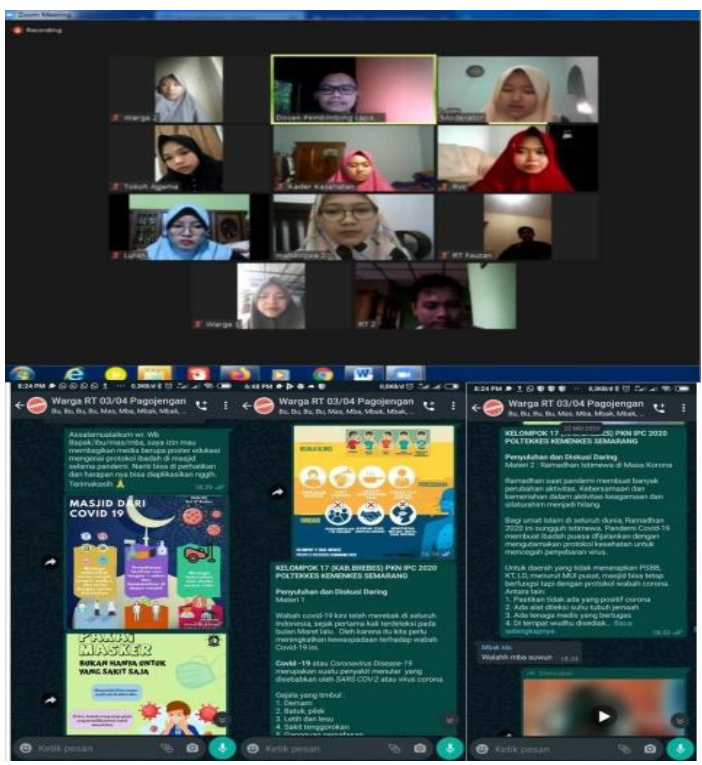

Figure 4. Online Meeting and Program Implementation

community as the front line in handling COVID-19 so that people need to be prepared with various knowledge and skills in preventing and controlling COVID-19. The implementation of this activity is expected to produce people who are able to independently manage COVID-19 problems in their surroundings by utilizing surrounding resources and can obtain support and build partnerships by involving various related parties (stakeholders), ranging from 
village governments, community leaders, religious leaders, health cadres, youth organizations, local health teams, organizations/institutions in the area around the community by providing assistance or support, both material and non-material. Most of the people work as farmers in the fields so they sunbathe while working.

The various carried out activities include health education, empowerment and partnerships. Nies and Mc. Ewen stated that the approach in handling the prevention and control of infectious diseases is in the form of community nursing interventions, namely by carrying out health education, community empowerment, group processes and partnerships. ${ }^{17}$ Prevention and control of COVID-19 in the community through health education interventions involving various parties such as community leaders, religious leaders, health cadres, COVID-19 officer units at the village level, students, and the local community were done with an active and continuous approach. Efforts to provide COVID-19 education must be conducted with a proactive approach and focus on the consistency of information provided by the government and related parties. ${ }^{18}$ Our program was emphasizing the importance of health education as the first step in raising public awareness and promoting health to address health challenge. ${ }^{19}$ Communitybased interventions are done through community empowerment by involving various stakeholders or "key persons" ranging from community leaders, religious leaders, health cadres, youth organizations, local health teams, organizations/institutions in the area around the community which aim to facilitate approaches with the community so that the intervention provided can be easily accepted by the community. In addition, empowerment is done to form community-based groups that take an active role in preventing and controlling COVID-19 starting from the family level and building networking with health workers, health facilities, and other parties.

Public health education during the pandemic was also conducted through the use of social media (WhatsApp) and home visits. Institutions or governments can use social media in providing health education to the public, especially in preventing the transmission of COVID-19. ${ }^{19}$ Social media has a great role in public health education because it enables the vast and speedy information dissemination related to COVID-19. This is only possible because social media has replaced the function of some people as facilitators in disseminating health information. ${ }^{20}$

In addition to using social media such as WhatsApp, health education in preventing the transmission of COVID-19 is also done through home visits in coordination with local health and village officials. Home visits are useful for monitoring public health, disseminating health information, providing hand washing facilities in front of community houses, distributing cloth masks and socializing its use and care as well as socializing pregnancy checks during the COVID-19 pandemic for pregnant women. Monitoring is carried out through visits by health workers in primary care settings in the form of body temperature checks and daily symptom screening. ${ }^{3}$

\subsection{Overview of the Evaluation of COVID-19 Prevention Activities in the Community}

Most of the community played an active role in the activities that have been planned. The community responded well in receiving health information provided by village volunteers. The success of providing health education to the public cannot be separated from the role of the used educational media. Apart from the use of social media, the use of print and electronic media such as posters or infographics and health videos greatly supports the success of the information provided. The use of infographics and videos was higher in effectiveness and provided $86 \%$ satisfaction compared to monologue formats in providing health information related to COVID-19. ${ }^{21}$ Educational media is part of a communication strategy in disseminating health information. Educational media such as posters, flyers, infographics and health videos are more effective in encouraging and directing the community. In addition, these educational media have a wide reach and may possibly help in raising the health and safety awareness. The use of graphic design accompanied by images on educational media can provide illustrations, visualize health interventions in the community, enhance health campaigns and can recruit people to jointly disseminate health information. ${ }^{22}$ 
Providing health education is accompanied by the application of community empowerment interventions and partnerships or cross-sectoral cooperation, which aim to encourage community participation in increasing preventive behavior against the spread of COVID-19. Community empowerment is conducted with the aim of exploring the potential of the community so that it is able to empower and encourage participate in preventing the transmission of COVID-19. Program activities were done in accordance with the guidelines for community empowerment set by the Ministry of Health. Community empowerment is conducted by collecting public health data, exploring factors that cause COVID-19 transmission and regional potential, conducting community meetings, draw up activity plans, carrying out activities to prevent COVID-19 transmission, and maintaining activities sustainability. ${ }^{6}$ The application of this health education can increase public knowledge in preventing and controlling COVID-19. This can be seen from the final evaluation of the implementation where the community is active and able to respond to materials about COVID-19 that have been given, starting from the understanding of COVID-19, causes, modes of transmission and prevention. People are willing to use masks when they are active because they already know how and the purpose of their use. Also, the community is able to practice 6 steps of washing hands with soap.

The implementation of education and community empowerment in the prevention of COVID-19 is strengthened by conducting partnerships or cooperation across sectors. Prevention of transmission and health education at the community level are essential for the implementation of cross-sector collaboration. ${ }^{23}$ In this activity, the implementation of crosssector cooperation includes the involvement of community leaders, religious leaders, health cadres, sub-district level COVID-19 officers, students, local community and especially the local government. Many health problems are handled by governments, demanding cooperation between national, regional or multilateral organizations, ${ }^{24}$ the strength of stakeholders and their networks, and the ability to map problems and solutions, which all play an important role in health policy, ${ }^{25}$ related to COVID- 19. The right policy is urgently needed for public health, and this requires collaboration between complex sectors and government agreement through various parties, the right collaboration has proven to be able to work well in dealing with COVID-19 even though there are differences in views between sectors or politics among stakeholders. ${ }^{26}$ In addition, there is a need for follow-up so that the program can be preserved, especially the implementation of health protocols in the new normal such as maintaining a minimum distance of 1.5 meters, using a mask, and washing hands in 6 steps. Supports from all levels of society are definitely demanded for a sustainable effort to prevent the transmission of COVID-19 in their respective regions. The limitation of this study lies in the evaluation technique. In this study, only a questionnaire was used. This research will be more complete if it includes behavioral observation techniques to prevent COVID-19 transmission.

\section{Conclusions}

Community knowledge and behavior to prevent COVID-19 are needed as an effort to increase public awareness about preventing COVID-19 transmission. Public health education continues to be carried out with various appropriate and efficient strategies so that people can easily understand the prevention of COVID-19 transmission. The local community is persistently urged to always continue performing preventive measures, including the proper handwashing practice, wearing masks, limiting outdoor activities, avoiding crowds, sunbathing, keeping physical distance followed by the process of studying, working and praying at home, and disinfecting objects/surfaces suspected of being infected by the corona virus. Empowerment and community cooperation with health services are expected to be able to prevent COVID-19 transmission. 


\section{Acknowledgment}

We express our gratitude for the Center of Research and Community Services Health Polytechnic of Ministry of Health for providing funding.

\section{Conflict of Interests}

There is no conflict of interest to declare.

\section{References}

1. Betz CL. COVID-19 and school return: The need and necessity. J Pediatr Nurs. 2020; 19-21.

2. McGarrigle L, Boulton E, Todd C. Map the apps: a rapid review of digital approaches to support the engagement of older adults in strength and balance exercises. BMC Geriatr. 2020; 20 (1): 1-12.

3. Indonesian KKRI. Guidelines for Community Empowerment in Prevention of COVID-19 in RT / RW / Village. Directorate General of Public Health, Directorate of Health Promotion and Community Empowerment. 2020. 0-36 p.

4. Fadli F, Safruddin S, Ahmad AS, Sumbara $S$, Baharuddin R. Factors influencing anxiety in health workers in COVID-19 prevention efforts. J Indonesian Nursing Educator. 2020; 6 (1): 57-65.

5. Syandri S, Akbar F. Using a face mask during prayers as a measure to prevent the COVID-19 Coronavirus Outbreak. SALAM J Sos and Syar-i Culture. 2020; 7 (3).

6. Indonesian KKRI. Guidelines for the Prevention and Control of Coronavirus Disease (COVID-19). Directorate General of Disease Prevention and Control. 2020; 0-115.

7. Li H, Zheng S, Liu F, Liu W, Zhao R. Fighting against COVID-19: Innovative strategies for Clinical Pharmacists. Res Soc Adm Pharm. 2020; April: 1-6.

8. Luo Y, Yao L, Zhou L, Yuan F, Zhong X. Factors influencing health behaviors during the coronavirus disease 2019 outbreak in China: an extended information-motivation-behavior skills model. Public Health. 2020; 185: 298305. Available from: https://doi.org/10.1016/j. puhe.2020.06.057

9. Maugeri G, Castrogiovanni P, Battaglia G, Pippi R,
D'Agata V, Palma A, et al. The impact of physical activity on psychological health during COVID-19 pandemic in Italy. Heliyon. 2020; 6 (6): e04315.

10. Anderson, ET and Mcfarlane J. Community as partner theory and practice in nursing. Philadelphia: Lippincott Williams \& Wilkins; 2011. 399 p.

11. Triyanto E, Kusumawardani LH. An analysis of people 's behavioral changes to prevent COVID -19 transmission based on integrated behavior model. Jurnal Keperawatan Sudirman. 2020; 15(2).

12. Bonell $C$, Melendez-Torres GJ, Viner RM, Rogers $\mathrm{MB}$, Whitworth $\mathrm{M}$, Rutter $\mathrm{H}$, et al. An evidencebased theory of change for reducing SARS-CoV-2 transmission in reopened schools. Health Place. 2020; 64 :102398.

13. Cuevas E. An agent-based model to evaluate the COVID-19 transmission risks in facilities. Comput Biol Med [Internet]. 2020; 121 (April): 103827. Available from: https://doi.org/10.1016/j. compbiomed.2020.103827

14. Chang KC, Strong C, Pakpour AH, Griffiths MD, Lin CY. Factors related to preventive COVID-19 infection behaviors among people with mental illness. J Formos Med Assoc [Internet]. 2020; (xxxx). Available from: http://www.sciencedirect. com/science/article/pii/S0929664620303442

15. Prasetyo YT, Castillo AM, Salonga LJ, Sia JA, Seneta JA. Factors affecting perceived effectiveness of covid-19 prevention measures among Filipinos during enhanced community quarantine in Luzon, Philippines: integrating protection motivation theory and extended theory of planned behavior. Int J Infect Dis [Internet]. 2020; Available from: http://www. ncbi.nlm.nih.gov/pubmed/32768695

16. Park T, Ju I, Ohs JE, Hinsley A. Optimistic bias and preventive behavioral engagement in the context of COVID-19. Res Soc Adm Pharm [Internet]. 2020;(June). Available from: https:// doi.org/10.1016/j.sapharm.2020.06.004

17. Nies, MA \& McEwen M. Community/public health nursing: promoting the health of populations. 6th ed. St. Louis: Elsevier Saunders; 2015.

18. Azlan AA, Hamzah MR, Jen $T$, Id S, Hadi S, Id 
A. Public knowledge, attitudes, and practices towards COVID-19: a cross-sectional study in. 2020;1-15.

19. Saxena A, Alhaboby ZA, Saxena A. Advocating the use of social media for health education in consideration of the SARS CoV-2 pandemic. Am J Biomed Sci Res. 2020; 8(5):532-4.

20. Sampurno MBT, Kusumandyoko TC, Islam MA. Budaya media sosial, edukasi masyarakat, dan pandemi COVID-19. SALAM J Sos dan Budaya Syar-i. 2020;7(5).

21. Peyravi $M$, Ahmadi Marzaleh $M$, Shamspour $\mathrm{N}$, Soltani A. Public education and electronic awareness of the new coronavirus (COVID-19): experiences from Iran. Disaster Med Public Health Prep. 2020;4-5.
22. Departemen Of Communication World Health Oraganization. WHO Strategic Communications Framework for effective communications. World Health Organization. 2017. 0-56 p.

23. Wahid EA. Pencegahan COVID19 di Komunitas. 2020

24. Buse K, Mays N, Walt G. Making Health Policy. 2016. DOI: $10.1163 / 9789004333109$

25. Parkhurst J, Ettelt S, Peters G. Evidence use in health policy making - International Series on Public Policy. 2018.

26. Raoofi A, Takian A, Sari AA, Olyaeemanesh A, Haghighi H. Iranian COVID-19 pandemic and comparative health policy learning in Iran. Acad Med Sci IR Iran. 2020;23(4):220-34. 